\title{
Amino Sugars in the Wall of Pseudomonas fluorescens
}

\author{
By S. G. WILKINSON \\ Department of Chemistry, University of Hull, Hull, HU6 7 RX
}

(Accepted for publication 20 November I97I)

\begin{abstract}
SUMMARY
3-Amino-3,6-dideoxy-D-galactose has been identified as a component of the wall of Pseudomonas fluorescens (NCTCIO038). This amino sugar was present in the lipopolysaccharide fraction of the wall: other amino compounds present were glucosamine, galactosamine, quinovosamine, alanine and ethanolamine. The distribution of amino sugars within different regions of the lipopolysaccharide was studied briefly.
\end{abstract}

\section{INTRODUCTION}

In addition to muramic acid, glucosamine and galactosamine (Wilkinson, 1970), amino sugars present in the wall of Pseudomonas fluorescens include quinovosamine (2-amino-2,6dideoxyglucose) and an unidentified compound, Unknown V (Wilkinson \& Carby, I97I). Unknown $\mathrm{V}$ has been identified as 3-amino-3,6-dideoxy-D-galactose and has been shown to occur in the lipopolysaccharide fraction of the cell wall.

\section{METHODS}

Pseudomonas fluorescens (NCTCI0038) was grown and its walls were prepared as described previously (Wilkinson, 1970). Methods for the isolation and characterization of amino sugars were those used in previous studies (Wilkinson \& Carby, 197I). Lipopolysaccharide was extracted from defatted walls (Fensom \& Gray, 1969) by a single treatment for $15 \mathrm{~min}$ at $72^{\circ}$ with $45 \%$ (w/v) phenol, and was purified by the method of Key, Gray \& Wilkinson (1970). The lipopolysaccharide was hydrolysed to lipid and polysaccharide fractions with I $\%$ acetic acid for I h at $100^{\circ}$ (Müller-Seitz, Jann \& Jann, I968). The crude polysaccharide was fractionated by chromatography on Sephadex G-50 (Schmidt, Jann \& Jann, 1969), and the eluate was analysed for phosphorus (Bartlett, 1959) and for carbohydrate (Dubois et al. 1956).

Infrared spectra were recorded by using a Unicam SP 200 spectrophotometer, with samples dispersed in discs of $\mathrm{KCl}$. Optical rotation was measured with a Bendix NPL automatic polarimeter, Model I43A.

\section{RESULTS}

Unknown $\mathrm{V}$ was present in the basic fraction obtained by high-voltage paper electrophoresis of wall hydrolysates (Wilkinson \& Carby, I97I), and was separated from basic amino acids and other amino sugars (quinovosamine, glucosamine and galactosamine) by preparative paper chromatography using solvent system A: ethyl acetate + pyridine + water + acetic acid $\left(5+5+3+\mathrm{I}\right.$, by vol.). Using solvent system A, unknown $\mathrm{V}$ had $R_{\text {glucosamine }} \mathrm{I} \cdot \mathrm{I} 9$ and on high voltage electrophoresis at $\mathrm{pH} 5 \cdot 3$ it had $R_{\text {glucosamiue }} \mathrm{I} \cdot 09$. The compound reduced alkaline $\mathrm{AgNO}_{3}$ strongly and reacted with ninhydrin on heating to give a bright yellow colour which changed to pink-purple on standing. A slight reaction, regarded as 


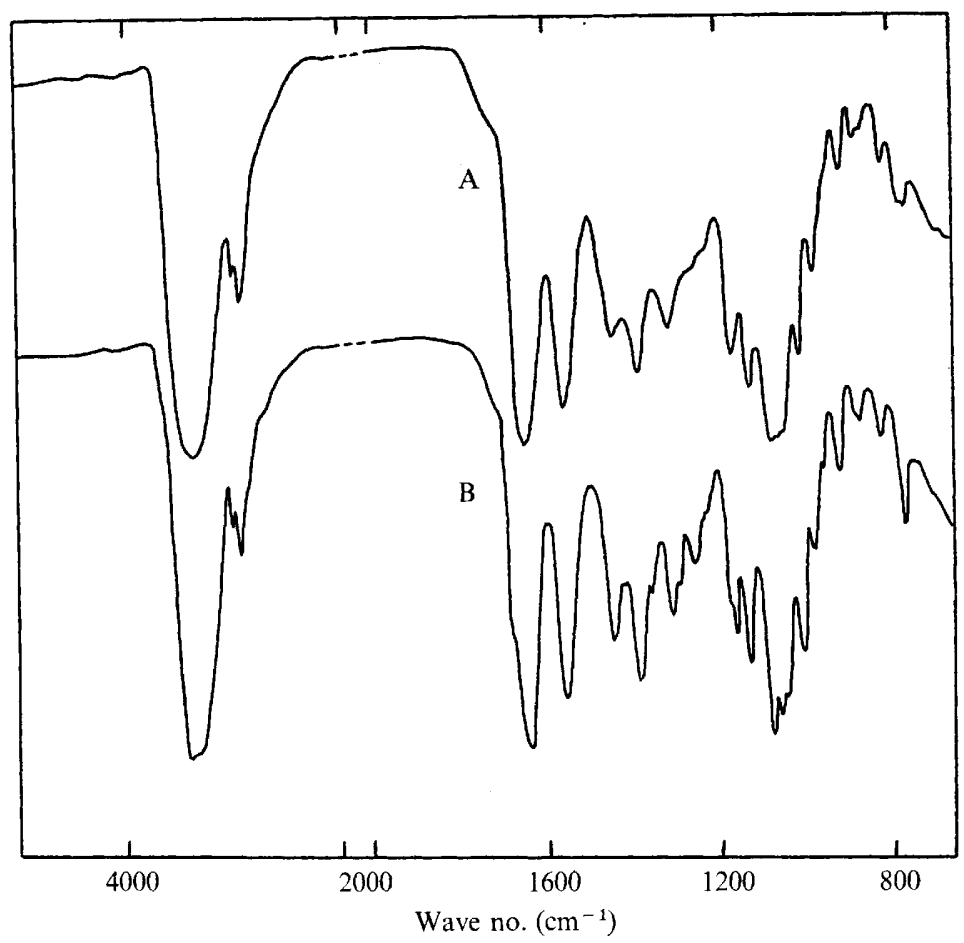

Fig. I. Infrared spectra of the $N$-acetyl derivative of Unknown V from Pseudomonas fluorescens (A) and of 3-acetamido-3,6-dideoxygalactose (B). The samples were dispersed in $\mathrm{KCl}$ discs.

negligible, was obtained in a test for 2-amino-2-deoxyhexoses (Rondle \& Morgan, 1955), but a test for 3-amino-3-deoxyhexoses (Ashwell, Brown \& Volk, I965) was strongly positive. Acetaldehyde was formed on oxidation of the compound with periodate. Thus, Unknown $\mathrm{V}$ had the properties of a 3-amino-3,6-dideoxyhexose.

On paper chromatography using solvent systems $\mathrm{A}$ and $\mathrm{B}-n$-butanol +acetic acid + water $(5+\mathrm{I}+2$, by vol.) - Unknown $\mathrm{V}$ had the same mobility as an authentic sample of 3-amino-3,6-dideoxygalactose and was clearly differentiated from 3-amino-3,6-dideoxyglucose. Unknown $\mathrm{V}$ and 3-amino-3,6-dideoxygalactose behaved identically in the following experiments: $(a)$ high-voltage paper electrophoresis at $\mathrm{pH} 5.3 ;(b)$ ion-exchange chromatography using a Technicon AutoAnalyzer; $(c)$ paper chromatography of the $N$-acetyl derivatives using three solvent systems; $(d)$ high-voltage paper electrophoresis in molybdate buffer ( $\mathrm{pH} 5^{\circ}$ ) of the amino sugar alcohols (Mayer \& Westphal, 1968). Although 3-amino-3, 6-dideoxygalactose and 3-amino-3,6-dideoxyglucose were virtually indistinguishable ( $R_{\text {glucosamine }}$ values $\mathrm{I} \cdot 28$ and $\mathrm{I} \cdot 29$, respectively, for successive chromatograms) using the AutoAnalyzer with a standard $2 \mathrm{I} \mathrm{h}$ elution system, resolution of the two amino sugars is possible with a pyridine-acetic acid buffer system, pH 3.85 (Brendel, Roszel, Wheat \& Davidson, 1967; Lüderitz et al. 1967). Insufficient $N$-acetyl derivative of Unknown V was available for crystallization, but the infrared spectrum of a dried sample closely resembled that of crystalline 3-acetamido-3,6-dideoxygalactose (Fig. I). The specific rotation determined with an aqueous solution of the $N$-acetyl derivative (concentration estimated using 3-acetamido-3,6-dideoxygalactose as standard) was $+110 \pm 4^{\circ}:[\alpha]_{\mathrm{D}}^{24}$ for 3-acetamido-3,6dideoxy-D-galactose is $+114^{\circ}$ (Ashwell \& Volk, I965). Thus Unknown V may be identified 


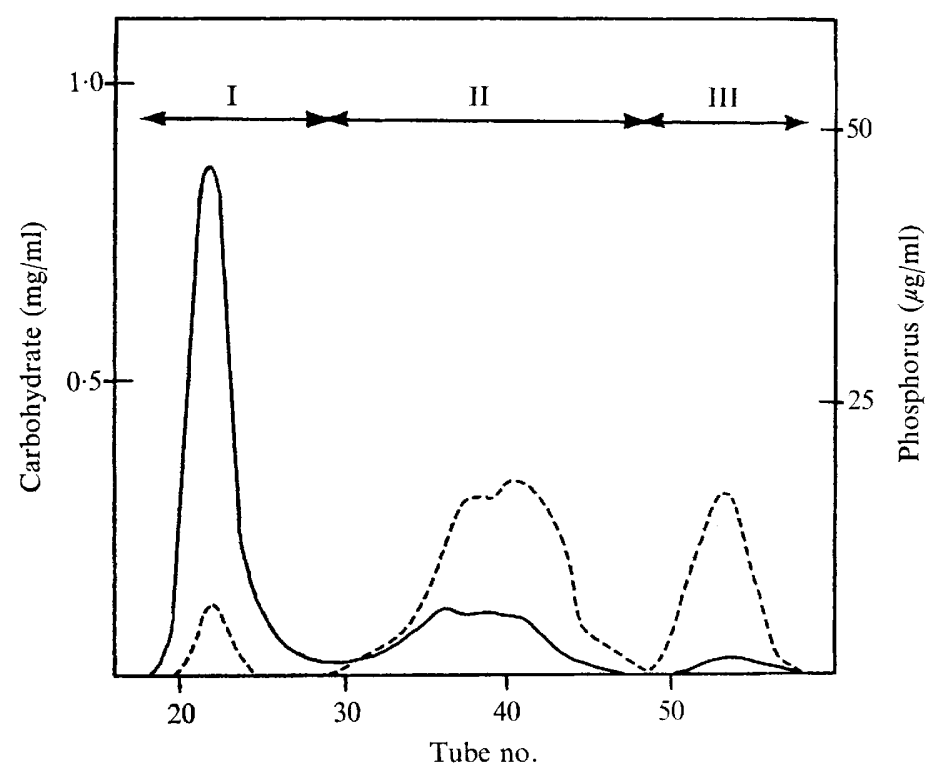

Fig. 2. Fractionation of partly degraded polysaccharide on Sephadex G-50. The material ( $10.5 \mathrm{mg}$ ) was applied to a column ( $50 \mathrm{~cm}$ length $\times 1 \cdot 2 \mathrm{~cm}$ diam.) and eluted with pyridine-acetic acid buffer $(\mathrm{pH} 5.4$ ) at a flow rate of $10 \mathrm{ml} / \mathrm{h}$. Fractions ( $\mathrm{I} \mathrm{ml)} \mathrm{were} \mathrm{screened} \mathrm{for} \mathrm{contents} \mathrm{of} \mathrm{phosphorus}$ $(-)$ and carbohydrate $(-)$ with glucose as standard.

as 3-amino-3,6-dideoxy-D-galactose. The yield of compound from Pseudomonas fluorescens was about $10 \mu$ moles/100 mg walls.

Analysis of the lipopolysaccharide fraction of the wall showed that glucosamine, galactosamine, quinovosamine and 3-amino-3,6-dideoxygalactose were all components, with the last-named being the major amino sugar. Other ninhydrin-positive components were alanine, ethanolamine and probably phosphates of both ethanolamine and glucosamine. The lipid A released on acid hydrolysis of lipopolysaccharide had only glucosamine and glucosamine phosphate as amino components: the remaining amino compounds and part of the glucosamine were present in the polysaccharide fraction. The partly degraded polysaccharide was separated on Sephadex G-50 into the three fractions indicated in Fig. 2. Fraction I contained most of the 3-amino-3,6-dideoxygalactose and only trace amounts of other amino sugars and alanine. Fraction II contained almost all the alanine, glucosamine, galactosamine and quinovosamine of the total polysaccharide, together with a small amount of 3-amino-3,6-dideoxygalactose and most of the ethanolamine and ethanolamine phosphate. Fraction III contained only small or trace amounts of amino compounds.

\section{DISCUSSION}

The presence of a 2-amino-2,6-dideoxyhexose (quinovosamine) and a 3-amino-3,6-dideoxyhexose in the lipopolysaccharide fraction from Pseudomonas fluorescens (and possibly $P$. synxantha, Wilkinson \& Carby, I97r) is unusual. Although amino sugars of both types occur in lipopolysaccharides from members of the Enterobacteriaceae, apparently they do not occur together in the same organism (Lüderitz, Jann \& Wheat, 1968). 3-Amino-3,6dideoxygalactose has been found in strains of Salmonella, Arizona, Escherichia and Citro- 
bacter (Lüderitz et al. I968; Keleti, Lüderitz, Mlynarčík \& Sedlák, I97I), as well as in Xanthomonas campestris, a member of Pseudomonadaceae (Ashwell \& Volk, 1965). As strain NCTC10038 has been proposed (Rhodes, I959) as the neotype strain for P. fluorescens biotype A (Stanier, Palleroni \& Doudoroff, 1966), it will be of interest to examine the lipopolysaccharides of other strains for the presence of unusual amino sugars. If the results obtained on gel filtration of the partly degraded polysaccharide (Fig. 2) can be interpreted in the same way as those of other similar experiments (e.g. Müller-Seitz et al. I968; Fensom \& Meadow, 1970), 3-amino-3,6-dideoxygalactose may be a component of the side-chain region of the polysaccharide and the other amino sugars and alanine are possibly components of the core region. Further studies will be necessary to establish this point.

I am grateful to Miss M. E. Bell and Miss L. Galbraith for assistance with parts of this work, and to Dr G. Ashwell, National Institutes of Health, Bethesda, Maryland, U.S.A., for a gift of 3-acetamido-3,6-dideoxy-D-galactose.

\section{REFERENCES}

Ashwell, G., Brown, N. C. \& Volk, W. A. (1965). A colorimetric procedure for the determination of $N$-acetylated-3-amino hexoses. Archives of Biochemistry and Biophysics 112, 648-652.

Ashwell, G. \& VolK, W. A. (1965). Isolation and identification of $N$-acetyl-3-amino-3,6-dideoxy-D-galactose, a cell wall constituent of Xanthomonas campestris. Journal of Biological Chemistry 240, 4549-4555.

BARTLETT, G. R. (1959). Phosphorus assay in column chromatography. Journal of Biological Chemistry 234, $466-468$.

Brendel, K., Roszel, N. O., Wheat, R. W. \& Davidson, E. A. (I967). Ion-exchange separation and automated assay of some hexosamines. Analytical Biochemistry 18, 147-160.

Dubois, M., Gilles, K. A., Hamilton, J. K., Rebers, P. A. \& Smith, F. (I956). Colorimetric method for determination of sugars and related substances. Analytical Chemistry 28, 350-356.

Fensom, A. H. \& Gray, G. W. (I969). The chemical composition of the lipopolysaccharide of Pseudomonas aeruginosa. Biochemical Journal rr4, I85-196.

Fensom, A. H. \& Meadow, P. M. (1970). Evidence for two regions in the polysaccharide moiety of the lipopolysaccharide of Pseudomonas aeruginosa 8602. FEBS Letters 9, 8I-84.

Keleti, J., LÜderitz, O., Mlynarčík, D. \& Sedlák, J. (I97I). Immunochemical studies on Citrobacter $\mathrm{O}$ antigens (lipopolysaccharides). European Journal of Biochemistry 20, 237-244.

Key, B. A., Gray, G. W. \& Wilkinson, S. G. (1970). Purification and chemical composition of the lipopolysaccharide of Pseudomonas alcaligenes. Biochemical Journal 120, 559-566.

LüDERITZ, O., JANN, K. \& WhEAT, R. (I968). Somatic and capsular antigens of Gram-negative bacteria. In Comprehensive Biochemistry, vol. 26A. Extracellular and Supporting Structures, pp. 105-228. Edited by M. Florkin \& E. H. Stotz. Amsterdam: Elsevier Publishing Co.

Lüderitz, O., RuschmanN, E., WestPhal, O., Raff, R. \& Wheat, R. (I967). Occurrence of 3-amino-3,6dideoxyhexoses in Salmonella and related bacteria. Journal of Bacteriology 93, I68I-I687.

MAYER, H. \& WestPhal, O. (I968). Elektrophoretische Trennungen von Hexosamin- und Hexuronsäurederivaten als Molybdatkomplexe. Journal of Chromatography 33, 5I4-525.

Müller-Seitz, E., JANN, B. \& J J E. coli $07 \mathrm{I}: \mathrm{K}$ ?:H12. Separation and investigation of $O$-specific and core polysaccharides. FEBS Letters I, 3II -3 I 4 .

RHODES, M. E. (1959). The characterization of Pseudomonas fluorescens. Journal of General Microbiology 21, $22 \mathrm{I}-263$.

Rondle, C. J. M. \& Morgan, W. T. J. (1955). The determination of glucosamine and galactosamine. Biochemical Journal 6r, 586-589.

Schmidt, G., JANN, B. \& JANN, K. (1969). Immunochemistry of R lipopolysaccharides of Escherichia coli. Different core regions in the lipopolysaccharides of $\mathrm{O}$ group 8. European Journal of Biochemistry ro, 50I-510. 
Stanier, R. Y., Palleroni, N. J. \& Doudoroff, M. (I966). The aerobic pseudomonads: a taxonomic study. Journal of General Microbiology 43, I 59-27I.

Wilrinson, S. G. (1970). Cell walls of Pseudomonas species sensitive to ethylenediaminetetraacetic acid. Journal of Bacteriology 104, 1035-1044.

Wilkinson, S. G. \& CARbY, K. A. (I97I). Amino sugars in the cell walls of Pseudomonas species. Journal of General Microbiology 66, 221-227. 